https://doi.org/10.31470/2706-7904-2021-16-54-63

РЕЗУЛЬТАТЫ КЛАСТЕРНОГО АНАЛИЗА СЕМАНТИЧЕСКИХ

ПРИЗНАКОВ «ЧЕЛОВЕКА ФЛИРТУЮЩЕГО»: «ПО ПОЛУ - КАКОЙ?», «ВНЕШНЕ - КАКОЙ?»

Results of Cluster Analysis of Semantic Features "What is the Person's Gender? and "What is the Person's Appearance?" for the Stimulus "Flirting Person"

\title{
Iya Gordienko-Mytrofanova
}

Dr. Sc. in Psychology, Professor

H.S. Skovoroda Kharkiv National Pedagogical University (Ukraine)

ikavgm@gmail.com

https://orcid.org/0000-0001-5332-0663

\section{Denis Hohol}

MA in Psychology

H.S. Skovoroda Kharkiv National Pedagogical University (Ukraine)

ReinRoz1803@gmail.com

https://orcid.org/0000-0002-4594-0720

\section{Serhii Sauta}

MA in Psychology

H.S. Skovoroda Kharkiv National Pedagogical University (Ukraine)

sergeisauta@gmail.com

https://orcid.org/0000-0002-1213-2655

\section{Maryna Konok}

MA in Psychology

H.S. Skovoroda Kharkiv National Pedagogical University (Ukraine)

marinekonyok1997@gmail.com

https://orcid.org/0000-0001-7457-9658

\section{Serhii Bezkorovainyi}

Postgraduate student

H.S. Skovoroda Kharkiv National Pedagogical University (Ukraine)

serechka3501@gmail.com

https://orcid.org/0000-0002-0246-2861 


\section{Abstract}

The present work continues a series of studies concerning ludic competence/playfulness by means of psycholinguistic instruments and is devoted to description of the behaviour pattern of the ludic position "Diplomat", which corresponds to flirting as one of the components of playfulness.

The key research method is psycholinguistic experiment whose main stage is the controlled association experiment (CAE) with the stimulus "flirting person". The sample consisted of 215 young respondents (age 21-35).

The instructions for the controlled association experiment was developed in the frame of the parametric concept of I.A. Sternin. 23 questions (semantic features) were formulated. They were recognized as relevant to communication for the stimulus "flirting person" and allowed to obtain the material for describing the behaviour pattern of ludic position Diplomat ("flirting person") reflecting the reality of linguistic consciousness of native speakers.

This study presents the results of cluster analysis of two association fields built for the following semantic features: "What is the person's gender?" and "What is the person's appearance?".

The results of cluster analysis of the association field built for the semantic feature "What is the person's gender?" indicate that in the linguistic consciousness of the inhabitants of Ukraine, the overwhelming majority of respondents (93\%) accept the binary concept of gender, for $3 \%$ of respondents gender does not matter, and only one respondent considers the transgender identity.

The analysis of the association field built for the semantic feature "What is the person's appearance?" allows us to assert that the absolute majority of respondents (78\%) demonstrates an emotionally positive attitude towards "flirting person".

Keywords: ludic competence, playfulness, flirting, youth, controlled association experiment.

\section{Introduction}

Вступ

The present work continues a series of studies devoted to ludic competencel playfulness and one of its components is flirting (Kobzieva, Gordiienko-Mytrofanova, Udovenko \& Sauta, 2020).

We define ludic competence as a system of inner resources to which a person turns in order to balance their personality against external conditions of the social environment on the basis of positive emotions, interest and joy, which are frequently expressed affectively and accompanied by tension and excitement. Formation of ludic competence implies developing playfulness as a stable personality trait. We determine playfulness as the individual creative adaptation to the reality of their own "Self" (individual identity) and to the reality of the "World" (social identity): every difficult / conflict situation can be faced as a challenge rather than a threat. 
The research of playfulness is carried out by means of psycholinguistic instruments. The research allowed to identify the components of playfulness and corresponding ludic positions: "sensitivity" (sensitive) - "Empath; "imagination” - "Sculptor"; "ease” (easy) "balance-master"; "flirting” (flirtatious) - "Diplomat”; “impishness" (impish) "Frolicsome fellow"; "humour" (funny) - "Real humourist”; "fugue” (fugue) - "Holy fool" (Gordiienko-Mytrofanova, Pidchasov, Sauta, \& Kobzieva, 2018).

Defined as "self-motivated abilities" (Raven, 2001), the components of playfulness as an integral personality trait are as well the components of ludic competence.

As it is mentioned above, flirting is one of the components of ludic competence/ playfulness.

The names of ludic positions are justified both theoretically and empirically and were tested during coaching sessions in ludic competence (CSLC), which are part of the curriculum of psychology students in H.S. Skovoroda Kharkiv National Pedagogical University (Kobzieva et al., 2020).

In the context of our ludic competence coaching sessions we consider flirting as the ability to take attention and get on the right side of somebody of the same or the opposite gender through verbal and non-verbal communication in order to establish and maintain mutually beneficial relationships based on the feeling of emotional bond. The ludic position «Diplomat» corresponds to flirting as a component of ludic competence/ playfulness (Gordienko-Mytrofanova, Kobzieva \& Hohol, 2021).

At the present stage the purpose of ludic competence/ playfulness study is, on the basis of applied psycholinguistic research, to broaden the content of the behaviour pattern of the ludic position "Diplomat" by means of identifying the semantic components of the stimulus "flirting person", which are actualized in the speech acts of Russian-speaking inhabitants of Ukraine.

\section{Methods and Techniques of the Research Методи і методики дослідження}

Our previous studies presented the results of the psycholinguistic experiment whose main stage was the free association test (SAT) with the stimulus "flirting" (GordienkoMytrofanova, Kobzieva \& Hohol, 2021). In this work we present intermediate results of the controlled association experiment (CAE) with the stimulus "flirting person". Additional methods included a survey (to clarify the results of the CAE), questionnaires (to clarify the characteristics of the sample). Frequency and cluster analysis were used as mathematical and statistical methods for analyzing the research results, which made it possible to identify trends in distribution of associations in the experimental group. 
The CAE with the stimulus "flirting person" was carried out in writing. According to the instructions, the respondents should indicate gender, age, education / specialty, marital status and write the first word that comes into mind when answering each question (semantic feature).

The total number of respondents who took part in the experiment was 215 young people (age 21-35), 112 females and 103 males. By education, 44\% per cent were undergraduates, 35 per cent had a university degree, 9 per cent completed secondary school; by marital status, 60 per cent were in a marriage-like relationship (unregistered marriage), $13 \%$ are in a registered civil marriage, $27 \%$ are not in a relationship.

At the early stage the procedure of formulating the instructions for the CAE with the stimulus "flirting person" also involved classifying and summarizing the results of theoretical and empirical psychological studies devoted to the phenomenon of "flirting"; classifying and summarizing the results of psycholinguistic studies devoted to the concept of "flirting" (Bern, 2017; Givens, 1978; Hall, 2013; Henningsen, Braz \& Davies, 2008; Rodgers, 1999; Whitty, 2003; Watzlawick, 1983 et al.).

Classifying and summarizing the results of psycholinguistic studies devoted to the concept of "flirting” (Gordienko-Mytrofanova, Kobzieva \& Hohol, 2021; Karaulov, 2002); defining the semantic features (instructions questions) for the stimulus "flirting person" was carried out in the frame of the parametric concept of I.A. Sternin on the base of the semantic aspects and corresponding semantic parameters described for the semantics of the names of persons (Sternin \& Rudakova, 2011: 132-140).

\section{Results \\ Результати}

We have formulated 28 questions (semantic features). The 28-question instructions were tested on a sample of 115 respondents (age 21-35). Based on the results of the analysis of the obtained associative fields, at the intermediary stage 26 questions were left. During the final stage of the study on a sample of 215 respondents 23 questions (semantic features) were selected. They were recognized as relevant to communication for the stimulus flirting person and allowed to obtain the material for describing the behaviour pattern of ludic position Diplomat ("flirting person") reflecting the reality of linguistic consciousness of native speakers (Gordienko-Mytrofanova, Hohol \& Nesterenko, 2021).

Since we are limited by the space of the article, the questions (semantic features) for the stimulus "flirting person" are presented without association the fields: 1. WHO IS THE PERSON AS A CARRIER OF THE FEATURE?

2. WHAT IS THE PERSON'S GENDER?

3. WHAT IS THE PERSON'S AGE? 
4. WHAT IS THE PERSON'S MARITAL STATUS?

5. WHAT IS THE STATE OF THE PERSON'S FINANCES?

6. WHAT SOCIAL CLASS DOES THE PERSON BELONG TO?

7. HOW INTELLIGENT IS THE PERSON?

8. HOW CULTURED IS THE PERSON?

9. WHAT IS THE PERSON'S MORAL STATURE?

10. WHAT ARE THE PERSON'S EMOTIONS?

11. WHAT IS THE PERSON'S APPEARANCE?

12. WHAT IS THE PERSON'S SELF-ESTEEM?

13. WHAT IS THE PERSON'S ATTITUDE TO THE OPPOSITE GENDER?

14. WHAT IS THE PERSON'S ATTITUDE TO THE SAME GENDER?

15. WHERE DOES THE PERSON FLIRT?

16. WHO DOES THE PERSON FLIRT WITH?

17. HOW POLITE IS THE PERSON?

18. WHAT IS THE PERSON IN SHOWING SENSE OF HUMOR?

19. WHAT IS THE PERSON'S BEHAVIOR?

20. WHAT IS THE PERSON IN THE EXPRESSION OF SEXUALITY?

21. WHAT IS THE PERSON'S MOTIVE?

22. WHAT IS THE PERSON IN CONFLICT?

23. WHAT IS YOUR OVERALL ASSESSMENT OF THE PERSON?

It is possible to find out more about the greater part of the association fields for each semantic feature and results of analysis of some association fields in one of our latest publications (Gordienko-Mytrofanova, Hohol \& Nesterenko, 2021).

In the present article we present the analysis of two more association fields built for the following semantic features:

2. WHAT IS THE PERSON'S GENDER?

11. WHAT IS THE PERSON'S APPEARANCE?

In the course of building an associative field for each semantic feature, the frequencies of reactions are calculated, and the frequencies of all reactions indicated by the corresponding number are presented in descending order. If the frequencies are equal, the responses go in alphabetical order. The number of respondents who declined to answer is indicated at the end of a built association field. The underlined reactions in the presented associative fields correspond in the original research to the feminine Russian words.

\section{WHAT IS THE PERSON'S GENDER? 215}

Female 104, male 92, wooden, doesn't matter 5, laminate, any, he 2, girl, red, transgender 1 .

"FEMALE": female 104, girl 1 - 105 (48.837\%), f. 41 (19.070\%), m. 64 (29.767\%). 
"MALE": male 92, he 2 - 94 (43.721\%), f. 65 (30,233\%), m. 29 (13.488\%).

“DOESN'T MATTER": doesn't matter 5, any 2 - 7 (3.256\%) f. 2 (0.930\%), m. 5 $(2.326 \%)$.

“THIRD GENDER": transgender 1 (0.465\%) f. (0.465\%).

Uninterpreted reactions: wooden 5, laminate 2, red $1-8$ (3.721\%), f. 3 (1.395\%), m. $5(2.326 \%)$.

The first two semes are false in terms of scientific philological analysis and are contamination with the meaning "The bottom floor in the room to walk on" (Efremova, 2000).

The reaction red among the uninterpreted ones, reveals a connection with the stimulus that is purely individual for the subject and incomprehensible to the researchers.

When grouping reactions for this semantic feature, we relied not on a binary gender system but on a gender conception that also comprises the transgender identity: "third sex or third gender is a term used to describe people who, by their own free will or as a result of social consensus, are not identified either as a man or a woman, as well as people who identify themselves or are ranked by society as a different gender that does not fit into the binary concept of gender. The term "third" usually means "other" ..." (McGee \& Warms, 2011).

\section{WHAT IS THE PERSON'S APPEARANCE? 215}

Attractive 55, beautiful 40, pretty 20, enticing 11, pleasant 10, sexy 7, comely 5, cute, charming 3, brunette, provocative, interesting, unusual, ordinary, average, bright 2, fucking awesome, crazy, blonde, bearded, brutal; European-looking girl, on the make, Italian, cool; which fits my human factors, life position, character; beautiful (for me); of low stature and skinny stature; childish face, any; masculine type, fashionable, manly, manly, quiet, outward, doesn't matter, awkward, normal, normal, awesome, deceitful, neat, repulsive, snobbish, splendid, common, pink, redhead, stunning, juicy, standard, strict, sexy, such, confident, mind-blowing, ugly, sophisticated, well-groomed, charismatic, extravagant, fuckable 1.

When distributing reactions in the context of this semantic feature, we relied on the criteria for assessing appearance described by Boguslavskij in his work 'Concept of person's appearance assessment' (Boguslavskij, 2004: 8-22).

1. “EMOTIONAL ASPECT" - 183 (85.116\%), f. 90 (41.860\%), m. 93 (43.256\%). In this cluster there are five subclusters:

1.1 "POSITIVE EVALUATION": attractive 55, beautiful 40, pretty 20, enticing 11, pleasant 10, sexy 7, comely 5, cute, charming 3, interesting, bright 2, fucking awesome, crazy, cool, quiet, splendid, stunning, sexy, mind-blowing, fuckable 1-168 (78.140\%), f. $82(38.140 \%)$, m. 86 (40.000\%);

1.2 "NEUTRAL EVALUATION": ordinary, average 2, normal, normal, common, standard $1-8(3.721 \%)$, f. $6(2.791 \%)$, m. 2 (0.930\%); 
1.3 "NEGATIVE EVALUATION": awkward, repulsive, ugly $1-3$ (1.395\%), f. 1 $(0.465 \%)$, m. 2 (0.930\%);

1.4 “NON-EVALUATIVE PERCEPTION": any, doesn't matter 1 - 2 (0.930\%), f. $1(0.465 \%)$, m. $1(0.465 \%)$;

1.5 "SUBJECTIVE AND PRAGMATIC": which fits my human factors, life position, character; beautiful (for me) 1 - 2 (0.930\%), m. 2 (0.930\%).

2. "EMOTIONAL AND MENTAL ASPECT": provocative, unusual, 2, brutal, on the make, manly, manly, deceitful, neat, snobbish, strict, confident, well-groomed, charismatic, extravagant - 16 (7.442\%), f. 11 (5.116\%), m. 5 (2.326\%).

3. “AESTHETIC ASPECT" - 10 (4.651\%), f. 7 (3.256\%) m. 3 (1.395\%).

This cluster also contains five subclusters:

3.1 “HAIR COLOUR": brunette, blonde, redhead 1 - 4 (1.860\%), f. 3 (1.395\%), m. $1(0.465 \%)$;

3.2 "NATIONALITY": european-looking girl, italian $1-2$ (0.930\%), f. 1 $(0.465 \%)$, m. $1(0.465 \%)$;

3.3 "HEALTHY": juicy $1(0.465 \%)$, f. (0.465\%);

3.4 "UNHEALTHY": of low stature and skinny stature 1 (0,465\%), f. (0,465\%);

3.5 "SECONDARY SEX CHARACTERS": bearded, masculine type 1 - 2 (0.930\%), f. $1(0.465 \%)$, m. $1(0.465 \%)$.

4. "SOCIAL ASPECT": fashionable, sophisticated 1 - 2 (0.930\%), f. 2 (0.930\%).

5. "AGE ASPECT": childish face - 1 (0.465\%), f. 1 (0.465\%).

Uninterpreted reactions: outward, such, pink $1-3$ (1.395\%), f. 1 (0.465\%), m. 2 $(0.930 \%)$.

Outward is referred by the authors to uninterpreted reactions as a pleonasm (Fomenko, 1994: 31).

Reactions with negative connotation: $f^{* * * i n g}$ awesome, of low stature and skinny stature; deceitful, repulsive, ugly, fu***ble $1-6$ (2.791\%), f. 4 (1.860\%), m. 2 (0.930).

\section{Conclusions}

Висновки

So, based on the results of cluster analysis, the semantic feature "WHAT IS THE PERSON'S GENDER?" is represented by four clusters: "FEMALE”, "MALE”, "DOESN'T MATTER", "THIRD GENDER". The first two are core clusters (more than 40\%), "DOESN'T MATTER" is peripheral (3\%) and the "THIRD SEX" cluster is represented by a single reaction. 
The semantic content of this semantic feature depends on gender identification according to the results of the analysis of the female and male association fields: male respondents (30\%) associate "flirting person" with female gender and only 13\% with male one, and, respectively, female respondents (30\%) associate it with male gender and $19 \%$ with female one. On the whole, the results of the analysis show that $49 \%$ of respondents associate "flirting person" with female sex and $43 \%$ with male one.

The results of cluster analysis indicate that in the linguistic consciousness of the inhabitants of Ukraine, the overwhelming majority of respondents (93\%) accept the binary concept of gender, for $3 \%$ of respondents gender does not matter, and only one respondent considers the transgender identity.

Semantic feature "WHAT IS THE PERSON'S APPEARANCE?” is represented by one core cluster "EMOTIONAL ASPECT" (85\%), two peripheral clusters "EMOTIONAL AND MENTAL ASPECT" (7\%) and "AESTHETIC ASPECT" (5\%), one cluster of the extreme periphery - "SOCIAL ASPECT" $(0.9 \%)$, and the "AGE ASPECT" cluster $(0.5 \%)$ is represented by a single reaction. The first two are core clusters (more than 40\%), the "DOESN'T MATTER" cluster is peripheral (3\%) and the "THIRD SEX" cluster are represented by a single reaction.

Analysis of the female and male association fields of the semantic feature in question did not reveal gender differences in the perception of the stimulus.

In general the analysis of this semantic feature allows us to assert that the majority of respondents $(78 \%)$ demonstrate an emotionally positive attitude towards "flirting person". There are $3 \%$ of reactions with negative connotation.

The semantic features (questions) for the stimulus "flirting person" described in this work make it possible to best reflect the content of the behavioral pattern of ludic position "Diplomat" (gender and appearance characteristics), which corresponds to flirting as a component of ludic competence / playfulness as a unit of psychological reality of linguistic consciousness of young Russian-speaking inhabitants of Ukraine taking into account the semantic components of the linguoculturological nature, which cannot be detected by the traditional methods of semantic analysis known today.

This research belongs to a number of scientific works devoted to the analysis and description of the concepts of culture and national linguistic pictures of the world. We see the prospect of further research in description of the association fields built for each semantic feature (question) in the instructions created in the frame of the parametric concept for the stimulus "flirting person". 


\section{References}

Bern, E. (2017). Igryi, v kotoryie igrayut lyudi: Psihologiya chelovecheskih vzaimootnosheniy. Lyudi, kotoryie igrayut v igryi: Psihologiya chelovecheskoy sudbyi [Games people play: The Psychology of human relationships. People who play games: The Psychology of human destiny]. FAIR-PRESS [in Russian].

Boguslavskij, V.M. (2004). Ocenka vneshnosti cheloveka [Assessment of human appearance]. Moscow: OOO «Izdatelstvo AST», pp. 8-22 [in Russian].

Efremova, T.F. (2000). Novyj slovar russkogo yazyka. Tolkovo-slovoobrazovatelnyj [New dictionary of the Russian language]. Moscow: Russkij yazyk [in Russian].

Fomenko, Yu.V. (1994). Tipy rechevyh oshibok [Types of speech errors]. Novosibirsk: NGPU [in Russian].

Givens, D.B. (1978). The nonverbal basis of attraction: Flirtation, courtship, and seduction. Interpersonal and Biological Processes, $\quad 41(4), \quad 346-$ 359. https://doi.org/10.1080/00332747.1978.11023994

Gordienko-Mytrofanova, I., Kobzieva, I., \& Hohol, D. (2021). Investigating the Concept of "Flirting" as Reflected in the Russian-Speaking Ukrianians' Linguistic Consciousness. Psycholinguistics, 29(1), 8-29. https://doi.org/10.31470/2309-1797-2021-29-1-8-29

Gordienko-Mytrofanova, I.V., Hohol, D.M., \& Nesterenko, M.A. (2021). Developing the instructions for the controlled association experiment by means of semantic features for the stimulus "flirting person". International Journal of Science Annals, 4(1), 5-6. https://doi.org/10.26697/ijsa.2021.1.4

Gordiienko-Mytrofanova, I., Pidchasov, Ye., Sauta, S., \& Kobzieva, Iu. (2018). The problem of sample representativeness for conducting experimental and broad psychological research. Psycholinguistics, 23(1), 11-46. https://doi.org/10.5281/zenodo.1212360

Hall, J.A. (2013). The five flirting styles: Use the science of flirting to attract the love you really want. Harlequin.

Henningsen, D.D., Braz, M., \& Davies, E. (2008). Why do we flirt? Flirting motivations and sex differences in working and social contexts. The Journal of Business Communication, 45(4), 483-502. https://doi.org/10.1177/0021943608319390

Karaulov, Yu.N., $\quad$ Cherkasova, G.A., Ufimtseva, N.V., $\quad$ Sorokin, Yu.A., $\quad \& \quad$ Tarasov, Ye.F. (2002). Russkiy assotsiativnyy slovar [Russian associative dictionary]. Astrel [in Russian].

Kobzieva, I., Gordiienko-Mytrofanova, I., Udovenko, M., \& Sauta, S. (2020). Concept "humour" in the linguistic consciousness of the Russian-speaking population of Ukraine. The European Journal of Humour Research, 8(1), 29-44. https://doi.org/10.7592/EJHR2020.8.1.kobzieva

McGee, R. J., \& Richard L. Warms. (2011). Anthropological Theory: An Introductory History. New York, McGraw Hill.

Raven, J. (2001). The Conceptualisation of Competence. New York: Peter Lang Publishing, Inc. 
Psycholinguistics in a Modern World - 2021. Proceedings of the 16th International Scientific and Practical Conference (Pereiaslav, Ukraine, December 16-17, 2021)

Rodgers, J.E. (1999). Flirting fascination. $\quad$ Psychology Today, 1.

https://www.psychologytoday.com/intl/articles/199901/flirting-fascination

Sternin, I.A, \& Rudakova, A.V. (2011). Psiholingvisticheskoe znachenie slova i ego opisanie. [Psycholinguistic meaning of the word and its meaning]. «Lambert» [in Russian].

Watzlawick, P. (1993). The situation is hopeless, but not serious (The pursuit of unhappiness). Revised ed. W. W. Norton \& Company. https://doi.org/10.1111/j.1545-5300.1984.121_8.x

Whitty, M.Th. (2003). Cyber-flirting: playing at love on the Internet. Theory \& Psychology, 13(3), 339-357. https://doi.org/10.1177/0959354303013003003 